\title{
Incidental finding of a large Morgagni's hernia in a 76-year-old lady
}

\author{
Aileen McCabe, Alan Watts, Adel Abdulrazak, Brendan McCann
}

Emergency Department, Waterford Regional Hospital, Waterford, Ireland

Correspondence to Dr Aileen Mc Cabe, aileenmccabe@rcsi.ie

\section{DESCRIPTION}

A 76-year-old lady presented after fracturing her distal radius in a mechanical fall. She had a background history of chronic obstructive pulmonary disease but at the time of her presentation to the hospital she had no acute medical issues. A routine chest radiograph done on her admission reported an enlarged right mediastinum with bowel gas (figure 1). Thoracic CT scans confirmed herniation of a segment of large bowel with associated omentum into the thorax through an anteromedial diaphragmatic defect, known as a Morgagni hernia (figures 2 and 3).

Although exact pathogenesis resulting in a Morgagni hernia are unknown, the primary defect is believed to be the embryonic failure of the diaphragm to close fully with abdominal organs herniating through the foramina of Morgagni located anteriorly adjacent to the xiphoid process of the sternum and contributing to pulmonary hypoplasia. First described in 1761, Morgagni's hernia account for $3 \%$ of congenital diaphragmatic hernias, with the most common type being the bochdalek's hernia (95\% of cases) which typically occurs on the left side of the chest wall through a postero-lateral diaphragmatic defect. ${ }^{1}$

In the adult population, Morgagni hernia presents with respiratory symptoms (recurrent chest infections, respiratory distress), gastroenterology symptoms (vomiting, constipation, gastric outlet obstruction and strangulation) and syncope while defaecating. ${ }^{2}$ Surgical repair is usually

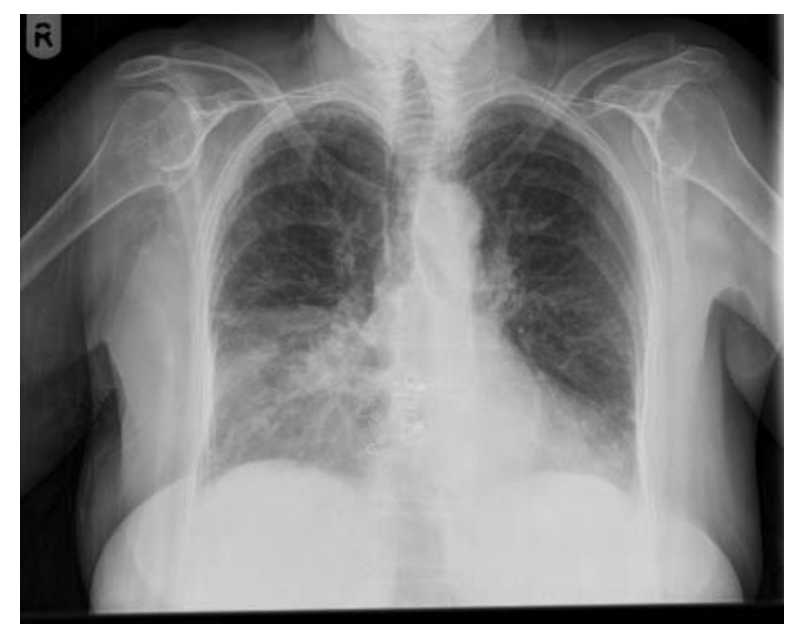

Figure 1 Chest radiograph demonstrating an enlarged right mediastinum with bowel gas.

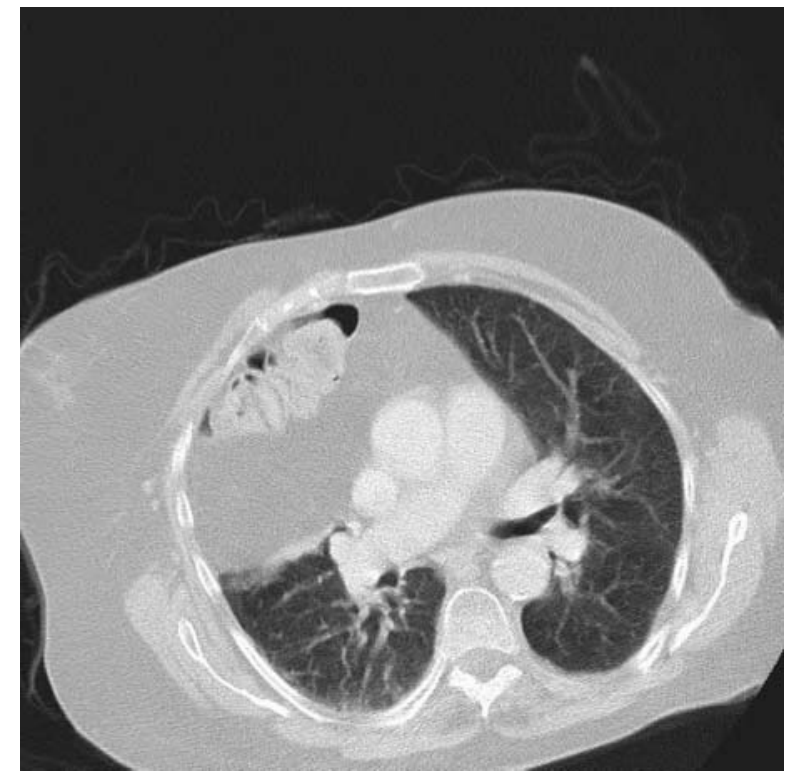

Figure 2 CT demonstrating herniation of a large bowel segment with associated omentum into the thorax.

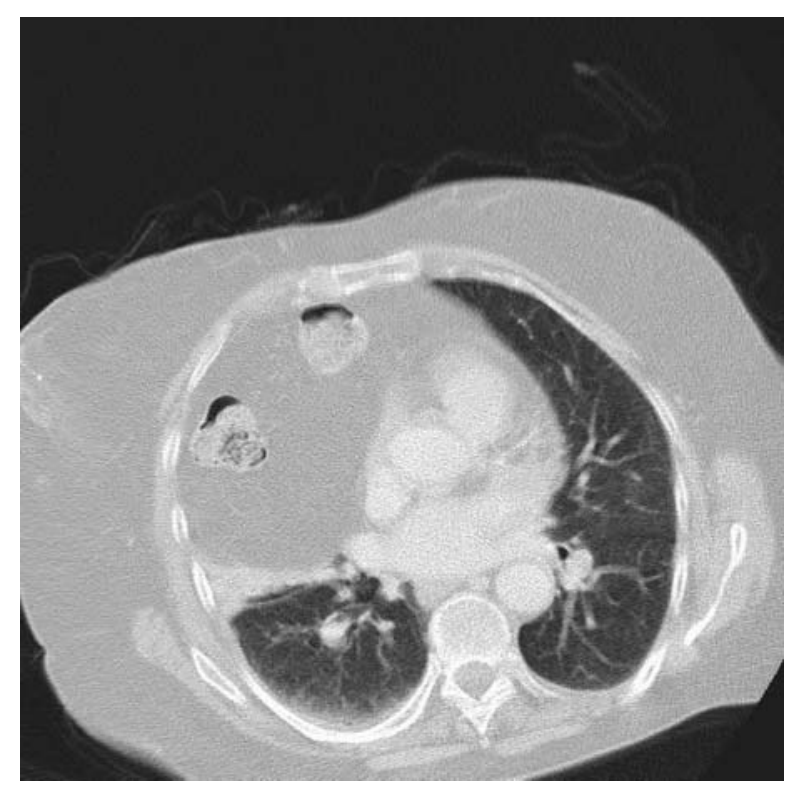

Figure 3 CT scans demonstrating two loops of large bowel in the thoracic cavity. 


\section{BMJ Case Reports}

done in acute phases and should be considered in asymptomatic cases to avoid future risk of surgical emergencies and death. ${ }^{1}$ In this case, the patient elected not to seek surgical repair and has continued to be asymptomatic.

\section{Learning points}

- Congenital diaphragmatic hernias are rare and can present with respiratory distress or gastroenterology symptoms such as vomiting, constipation preceding surgical emergencies such as gastric outlet obstruction and strangulation.

- Gold standard diagnostic modality is CT.

- Treatment is via surgical repair and should be considered in asymptomatic patients to avoid future surgical emergencies.

\section{Competing interests None}

Patient consent Obtained.

\section{REFERENCES}

1. Shields TW, LoCicero J III, Reed CE, et al., eds. General thoracic surgery. Volume 1. 7th edn. Philadelphia: Lippincott, Williams \& Wilkins, 2009.

2. White DC, McMahon R, Wright T, et al. Laparoscopic repair of a Morgagni hernia presenting with syncope in an 85-year-old woman: case report and update of the literature. J Laparoendosc Adv Surg Tech 2002;12:161-5.

3. Lev-Chelouche D, Ravid A, Michowitz M, et al. Morgagni hernia: unique presentations in elderly patients. J Clin Gastroenterol 1999;28:81-2.

This pdf has been created automatically from the final edited text and images.

Copyright 2012 BMJ Publishing Group. All rights reserved. For permission to reuse any of this content visit http://group.bmj.com/group/rights-licensing/permissions.

BMJ Case Report Fellows may re-use this article for personal use and teaching without any further permission.

Please cite this article as follows (you will need to access the article online to obtain the date of publication).

McCabe A, Watts A, Abdulrazak A, McCann B. Incidental finding of a large Morgagni's hernia in a 76-year-old lady. BMJ Case Reports 2012;10.1136/bcr-2012007175, Published XXX

Become a Fellow of BMJ Case Reports today and you can:

- Submit as many cases as you like

- Enjoy fast sympathetic peer review and rapid publication of accepted articles

- Access all the published articles

- Re-use any of the published material for personal use and teaching without further permission

For information on Institutional Fellowships contact consortiasales@bmjgroup.com

Visit casereports.bmj.com for more articles like this and to become a Fellow 